\title{
Tobati Enggros Village Tourism Development Model In Community Income Increasing Strategy In Jayapura City
}

\author{
Yohanis Rante dan Westim Ratang \\ Universitas Cenderawasih Papua \\ Andika Rante \\ Universitas Cenderawasih Papua
}

\begin{abstract}
ABSTRACK
Tobati Village and Enggros Village can only be reached by using sea transportation, because it is located in the middle of Youtefa Bay, while transportation is provided by the community traditionally, and only limited to meeting daily needs, so that if there are tourists who want to visit the area of Youtefa Bay attractions must first contact the local community to prepare the boat. There are several alternative wharves to reach the Youtefa Bay area, namely: Jetty at Hamadi Beach, Muara Sungai Hquiry, Vim Beach, Abe Beach and Tanah Hitam. The purpose of this study are as follows: (1) To find out and analyze the inhibiting factors and supporting factors in improving the tourism of Tobati Enggros Village in Jayapura City. (2). To produce a strategy in developing tourism potential of Tobati Enggros Village in Jayapura City. (3) To produce a tourist model of Tobati Enggros Village in Jayapura City and (4). To find out the income of the people in Tobati Enggros Village in Jayapura City. Data analysis techniques are three analytical tools, namely, qualitative descriptive analysis (liker scale) to quantitative descriptive analysis and SWOT analysis through approaches commonly known as Strength Analysis, Weaknesses, Opportunities and Threats or SWOT Analysis (Strengths, Weakness, Opportunities and Threats). The results showed that the strategy for Tobati Enggros village tourism was a strategy: (1) With special autonomy the government was able to increase the availability of human resources who understand tourism potential and how to develop tourism and can increase the allocation of funds. (3) Technological progress must be able to be utilized to develop tourism governance and the quality of human resources. (4) The development and progress of the tourism sector in Indonesia is able to become an important capital to improve tourism promotion that is still lacking. (5) The strategic location and distance between villages that are increasingly integrated make a great opportunity so that the government is able to allocate funds to improve roads and improve governance. (6) Increasing economic growth can make opportunities to be able to increase competitiveness so that it will be able to increase the quantity and quality of human resources. There are 4 (four) models for the development of Tobati and Enggros tourist villages, namely: the development model of villages (1) cultural tourism, (2) water sports tourism, (3) natural tourism, and (4) historical tourism.
\end{abstract}

Keywords: Model of Development, Tourism, Tobati Enggros, SWOT, Strategy

\section{BACKGROUND}

Tobati Village and Enggros Village can only be reached by using sea transportation, because it is located in the middle of Youtefa Bay, while transportation is provided by the community traditionally, and only limited to meeting daily needs, so that if there are tourists who want to visit the area of Youtefa Bay attractions must first contact the local community to prepare the boat. There are several alternative docks to reach the Youtefa Bay region, namely: Jetty at Hamadi Beach, Estuary of the River Hquiry, Vim Beach, Abe Beach and Tanah Hitam. One of the most basic tourist needs is to eat drink, currently in Tobati Enggros village there is no place to 
eat provided by the community, but if there are orders from visitors in advance the community is prepared to prepare it, this is due to the fact that tourists have not routinely visited Youtefa Bay attractions, as for local foods that can be provided by the community are: papeda, grilled fish, squid, shrimp , crabs, satay bia and others. All these food ingredients are available in this area. Objects and Tourist Attractions of Tobati Enggros Village (Youtefa Bay region) has historical tourism objects in the gospel in Tabi which has now been built into the Gospel Entry Monument in Jayapura City, a heritage tourism object of the Second World War, tourists can also watch or together people fishing traditionally, playing ball in water, the field arises sinking at times when low tide can be used as a place to play football.

With the establishment of Tobati \& Enggros village as a tourist village and supported by community conditions that are friendly to visitors, the community consciously understands the benefits of tourism development by reflecting SAPTA PESONA, then slowly this village will begin to be visited by tourists. This of course will be able to move the economy of the village community, along with the program launched by the Governor of Papua, namely building communities starting from the village.

Tourism activities in the Youtefa Bay area will later be an activity that can be used as a stimulus (stimulation) for regional development on a cross-sectoral basis, because of the tourism assets that have a rare influence or presence, especially at the regional level for tourism development in this area which is accompanied and supported by activities. other activities appropriately and in an integrated manner, the benefits of tourism activities will be felt by all regions, especially participating in filling in regional development programs, although development plans cover only the area, these assets in general and overall are regional development plans with tourist objects as components - the main component.

What is desirable from a regional development is that tourism objects that have been developed will later stimulate sectoral activities starting from the surrounding area and then at the regional level. In accordance with the limitations and characteristics of tourist villages, the product model that can be offered must reflect the rural atmosphere that is attempted as much as possible with the original atmosphere. Some types of attractions that might be developed. Activities of fishermen: tourists are directly involved with fishing activities on the beach after going to sea, such as pulling nets, fishing by boat or catching fish with arrows.

Tourist attractions related to village community art activities such as dance, sculpture, carving, music that really originated and took place in the village. Tourist attractions related to traditional activities or village ceremonies, tourists involved / participate (active / passive) in the preparation or implementation of village ceremonies with certain requirements without reducing the sacredness and cultural values or religious of the ceremony. Tourist attractions related to sports, in this Youtefa Bay tourism area can also be developed several water sports activities such as: jet sky, canoeing, banana bout, water bikes and at certain times where the sea is receding to Debi Island attractions activities can be carried out by sports such as footballs, volleyball, kites and others.

\section{RESEARCH METHODS}

Grouping and Data SourcesIn this research using primary data and secondary data.1) Primary data, collected through monitoring, surveys, observations and semi-structural interviews with local communities by distributing questionnaires, namely, serving people (fishermen, community leaders, ondoafi, chiefs, government). 2) Secondary Data, collected from literature related to this research in the form of data on the profile of the local area, and utilization of 
fisheries and natural tourism products. Secondary data were also obtained from the statistical office, the local Tourism Office, the Fisheries and Maritime Service of Jayapura City.

\section{Number of Samples and Method of Sampling}

\section{Total population}

Enggros Village, the number of households is 120 families and Tobati village, the number of family heads is 87 families. The number of family heads of indigenous people (Fishermen) who utilize fisheries and natural tourism is 307 heads of households are the population.

\section{Number of samples}

Of the 307 heads of households, $15 \%$ will be taken, then Enggros Village is 120 families, so the sample is 18 families and Tobati Kampong is 87 families, so the sample is 14 as a sample, totaling 32 respondents

\section{Analysis Method}

1) Qualitative analysis, used to evaluate, identify and explain with descriptions and tables above:

\section{2) Quantitative Analysis}

This analysis is used to measure the views, income, perceptions or responses of the public about the utilization of fishery products and natural tourism in order to increase the income of the Tobati Enggros community.

\section{3) Variable measurement scale}

Measurement scale using a Likert scale. The lowest score was given a scale of 1 and the highest was given a scale of 5 with levels

\section{4) SWOT analysis}

Using the SWOT analysis will be able to obtain an overview of the strengths / strengths of what is owned by the Tobati and Enggros Village communities for fisheries or natural resource potential and the weaknesses they have in developing fisheries and natural tourism businesses.

\section{Characteristics of Respondentsa. Tobati Village}

\section{RESULTS AND DISCUSSION1.}

\section{1) Based on Gender}

Characteristics of respondents based on gender from questionnaires distributed as many as 32 questionnaires, it appears that women as much as $53 \%$ or amounting to 17 people and men as many as $47 \%$ or amounting to 15 people.

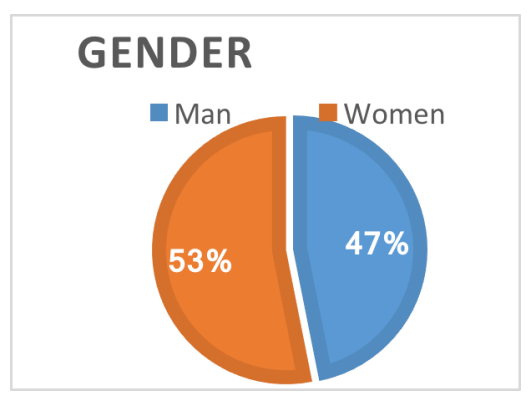




\section{2) Based on Age Group}

Characteristics of respondents based on age groups showed that age $31-40$ years were $34 \%$ or 11 people.

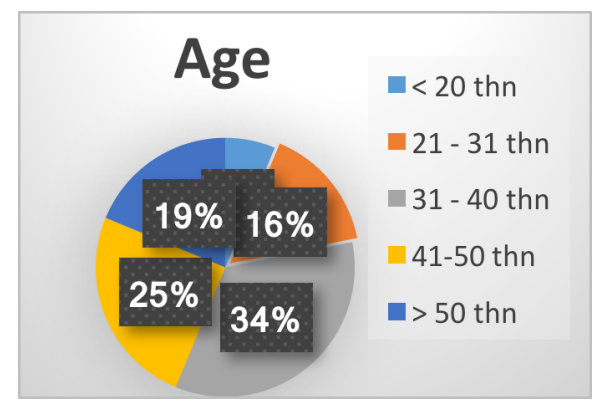

\section{3) Based on Job}

The people in Tobati village generally work as fishermen, which are 15 people, 8 traders, 5 housewives, 1 employee, 1 civil servant and 2 students.

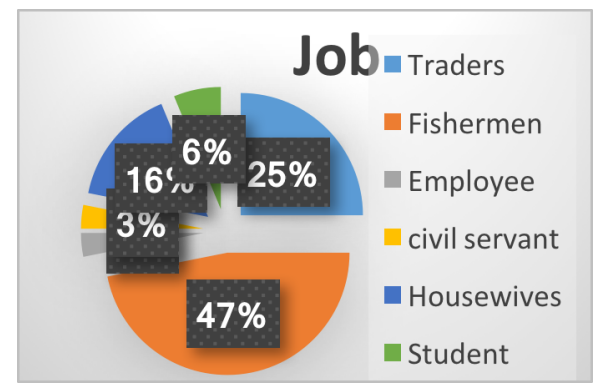

\section{4) Based on Revenue}

In general, the people in Tobati Village are fishermen because the people live in the sea. In general, community income is in 1 month Rp.1,000,000 - Rp.2,900,000, which is 12 people,

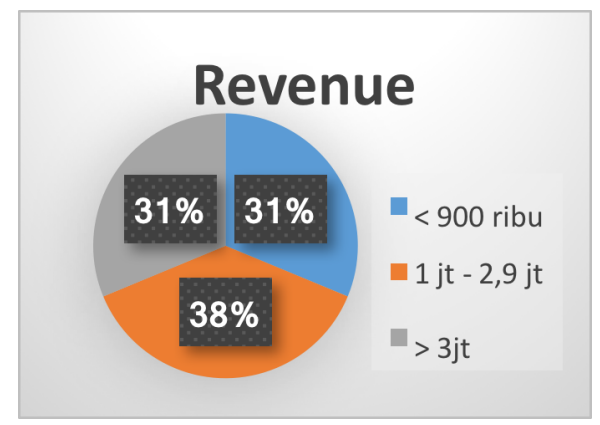

\section{5) Based on Education Level}

Based on the questionnaires collected from 32 respondents based on the highest level of education, the level of high school education was 13 people.

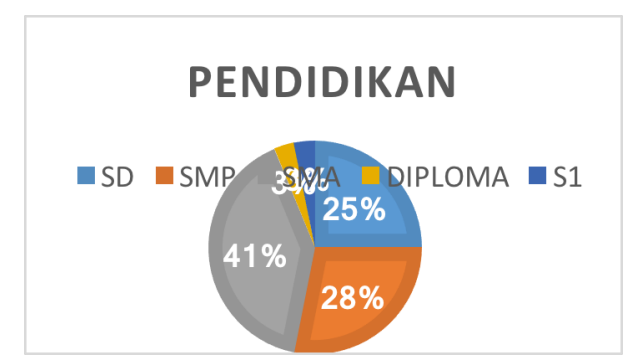




\section{Development Model of Tourist Village}

\section{a) Cultural Tourism Development Model}

Cultural tourism is a trip that is carried out on the basis of a desire to broaden one's life view by making a visit or review elsewhere or abroad, studying the condition of the people, their customs, their way of life, their culture and art. Along with this trip, it is united with opportunities to take part in cultural activities, such as art exposition (dance, drama, music, and sound art), or historical motives and so on.

Tobati Enggros Village cultural tourism, this area has a strategic location for tourism development. The strategic location of this area is very potential in attracting domestic and foreign tourists, especially supported by the ease of sea accessibility which will primarily provide infrastructure that is in accordance with standards. Tourism activities in this region tend to occur intra-region. Promotion and marketing have not focused on the international tourist market, but are temporarily limited to local and regional markets for recreational and pilgrimage activities. In tourism development in this region, the concept of cultural tourism development must be a reference. With this concept, tourism is expected to show the identity of the community of Tobati Enggros village.

With this cultural tourism development model mindset, it can be analyzed the direction of tourism development with a directed and integrated various aspects of regulation, objects, and management into important aspects. On the regulatory aspect, it is necessary to issue Regional Regulations, Jayapura Mayor Regulations, and Jayapura Mayor's Decree as a concrete manifestation of concern in developing cultural tourism as an asset that can improve PAD and people's economic life in a good direction. Thus the policy direction for developing cultural tourism objects with cultural and environmental perspectives will lead to the preservation of cultural elements as superior objects in the development of tourism. For this reason, development in various supporting aspects such as art (dance, music, painting), unique customs, and also matters relating to aspects of trust in various environments, nature, rivers, trees, or various other customary activities sacred can be developed in various tourism development programs in Tobati Enggros village.

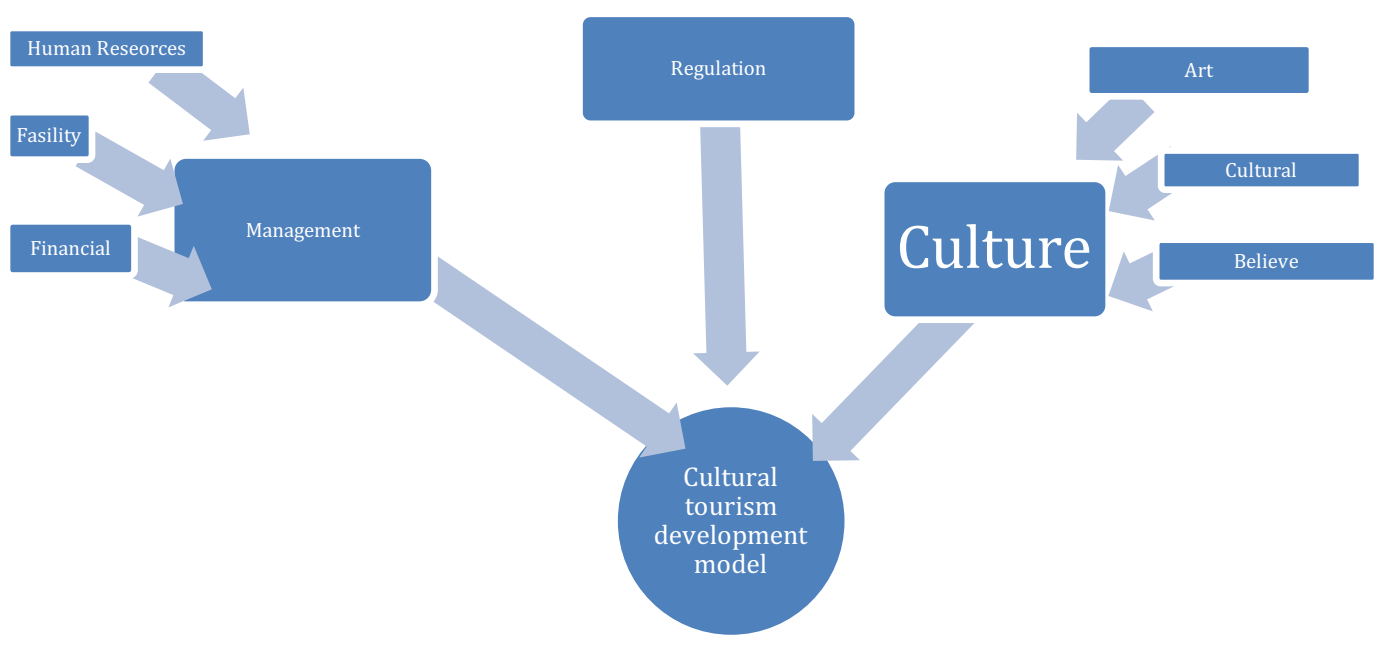

Likewise with management aspects as one aspect that needs to be considered in the effort to develop tourism. Management aspects play an important role in supporting the development of tourism, especially in relation to human resources, facilities and finance. The programs will be well directed with good management in the effort of developing human resources both at the level of the apparatus of culture and tourism as well as community resources as 
stakeholders of cultural customs as cultural tourism objects. Management aspects related to facilities are very important because related to the efforts to develop a cultural studio, traditional houses can be well realized as concrete steps in implementing tourism development by looking at the importance of cultural tourism.

The important things in management related to finance are the supporting elements that need to be considered and arranged properly. Financial management is well formulated in managing efforts to find financial resources, financial allocation and financial management in a transparent, accountable and unqualified manner (WTP) is good support in the operationalization of cultural tourism development as a tourism development target in Tobati Enggros village. With this framework, the efforts to develop programs in accordance with the regional tourism development master plan can be realized well and directed.

\section{b) Historical Tourism Development Models}

This tour is more or less associated with religion, history, customs and beliefs of people or groups in society. Pilgrimage tours are mostly carried out by individuals or groups to holy places, to the tombs of great people or leaders who are honored, to a hill or mountain that is considered sacred, a place of burial of a figure or leader as a magical human full of legends. This pilgrimage tour is much associated with the intention or desire of the tourists to obtain blessings, inner strength, determination of faith and not infrequently for the purpose of obtaining blessings and abundant wealth. With accommodation facilities and transportation facilities that are given attractive reductions to these places.

With this model, elements of management, regulation and objects become important targets in the development of historical tourism, so the policy direction is focused on several important elements. The management element needs to be an increase in human resources both in the Culture and Tourism Office, as well as the community that owns the tourism assets. The main support is also the financial aspect as the wheel of the policy that is proclaimed, as well as the aspects of supporting historical tourism development facilities need to be well organized and prepared. In connection with regulatory elements, the government in this case the governor and mayor need to issue regional regulations, mayor regulations, and mayor's decree as official documents in an effort to raise the development of historical tourism properly. The element of the object becomes the main holder of the role in the development of historical tourism, especially in the effort to organize, restore, and maintain historical sites well. 


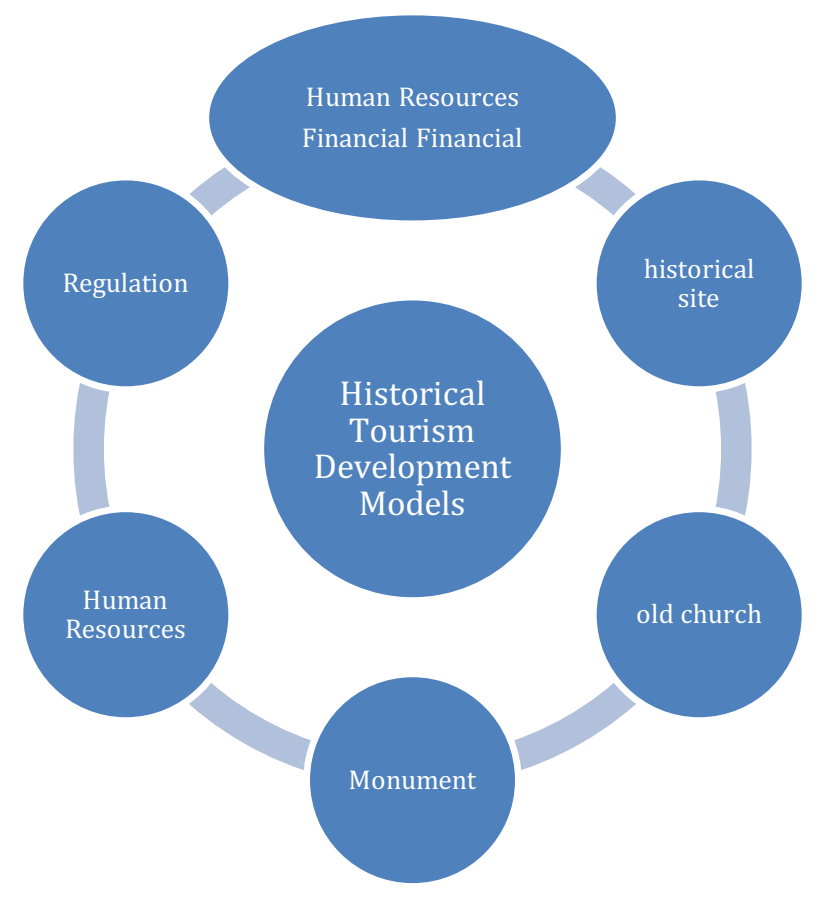

\section{c. Natural Tourism Development Model}

Nature tourism is mostly organized by agents or travel agencies that specialize businesses by arranging tours to places or areas of nature reserves, protected parks, mountainous forest areas and so on whose conservation is protected by law. This nature reserve tour is mostly carried out by fans and nature lovers in relation to the penchant for photographing animals or genera of colorful animals and flower trees that do get protection from the government and society. This tour is often associated with the passion for natural beauty, the fresh air in the mountains, the wonders of the lives of animals and clans of rare animals and plants that are rarely found in other places.

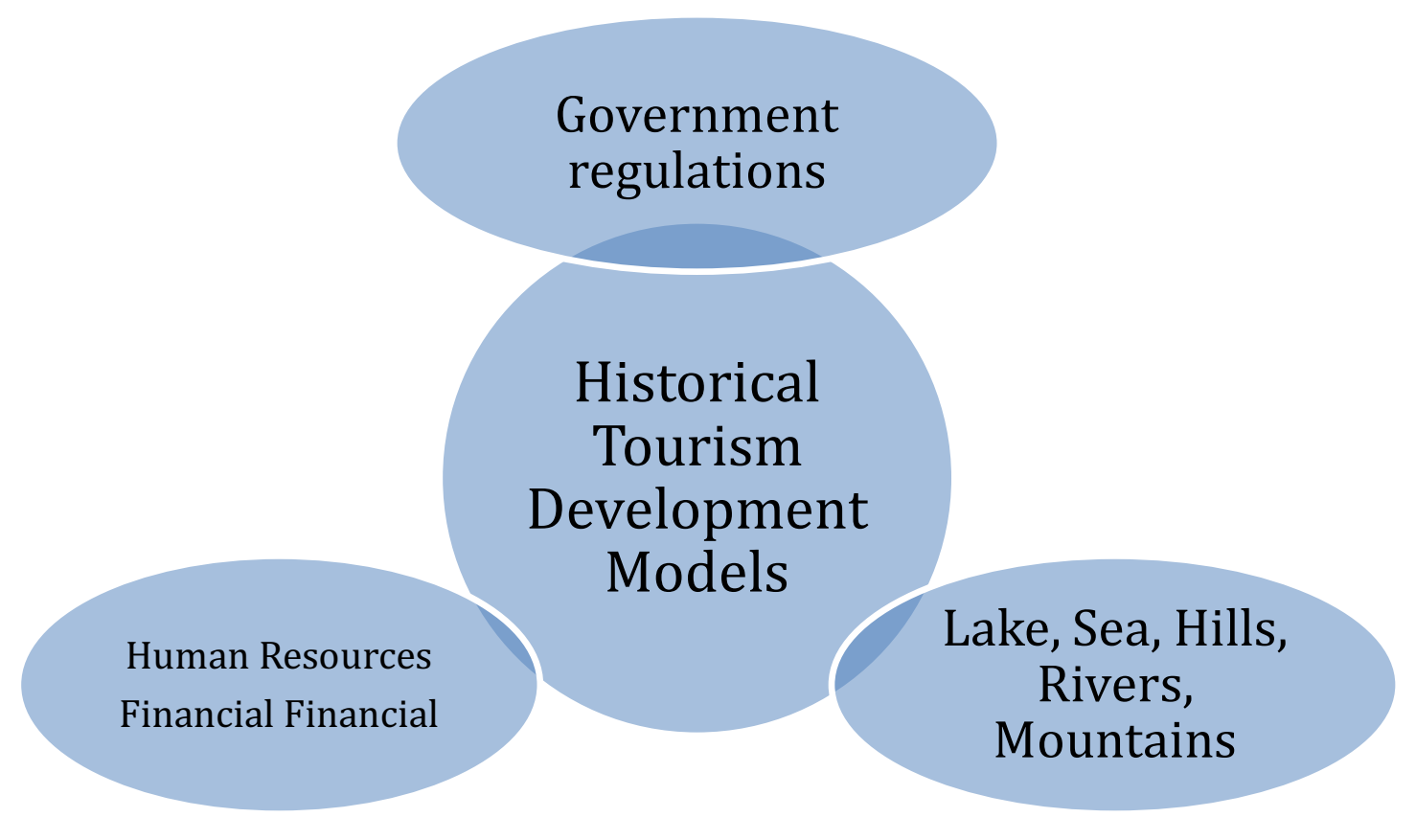




\section{Development Strategy of Tobati Enggros Tourism Village in Jayapura City}

The strategy for the Tobati Enggros village tour is the WO Strategy:

a. With special autonomy the government is able to increase the availability of human resources who understand tourism potential and how to develop tourism and can increase the allocation of funds.

b. The government must be able to streamline expenditure costs.

c. Technological progress must be able to be utilized to develop tourism governance and the quality of human resources.

d. Development and Progress of the tourism sector in Indonesia is able to become an important capital to improve tourism promotion that is still lacking.

e. The strategic location of the region and the distance between villages that are increasingly integrated make it a great opportunity so that the government is able to allocate funds to improve roads and improve governance.

f. Increasing economic growth can make opportunities to be able to improve competitiveness so that it will be able to increase the quantity and quality of human resources.

\section{CONCLUSIONS AND RECOMMENDATIONS}

1. The profile of the population in the Tobati Enggros village generally works as fishermen, the average level of education is high school, and the income of the community that most of the fishermen are $1,000,000$ to $2,000,000$ per month.

2. The strategy for the Tobati Enggros village tour is the WO Strategy:

a. With special autonomy the government is able to increase the availability of human resources who understand tourism potential and how to develop tourism and can increase the allocation of funds.

b. The government must be able to streamline expenditure costs.

c. Technological progress must be able to be utilized to develop tourism governance and the quality of human resources.

d. Development and Progress of the tourism sector in Indonesia is able to become an important capital to improve tourism promotion that is still lacking.

e. The strategic location of the region and the distance between villages that are increasingly integrated make it a great opportunity so that the government is able to allocate funmds to improve roads and improve governance.

f. Increasing economic growth can make opportunities to be able to improve competitiveness so that it will be able to increase the quantity and quality of human resources.

3. There are 4 (four) models for the development of Tobati and Enggros tourism villages, namely: the development model of villages (1) cultural tourism, (2) water sports tourism, (3) natural tourism, and (4) historical tourism.

\section{Recomendations}

1. Development of Tourism Resources need to do education and training, open vocational schools, diplomas and S1, foreign language courses and management in the field of tourism.

2. For the local government it is necessary to have a master plan for the preparation of synergies between the provincial, city, sub-district, and village governments in the development of a tourist village development strategy.

3. For the local government there needs to be a regulation that regulates the implementation of tourist villages with certain parameters to avoid the emergence of tourist villages that are not in accordance with the rules of the tourist village itself. 
4. For the community there needs to be a consideration that the determination of the area as a tourist village area should not result in a decrease in environmental quality.

5. Need to promote with the aim of building awareness, increasing knowledge, and increasing public understanding of tourism villages along with tourism potential, especially the beauty of nature, art and culture.

\section{Reference}

Anonim. 2012. Makalah konsevasi.http://purnamaegha.blogspot.com/2012/10/ makalah-konservasi.html. Diakses 09 September 2014.

Fandeli, C. 2001. Perencanaan Kepariwisataan Alam. Yogyakarta: Fakultas Kehutanan UGM.

Hastuti dan Dyah Respati SS. 2009. Model Pemberdayaan Perempuan Miskin

Berbasis Pemanfaatan Sumberdaya Perdesaan Upaya Pengentasan Kemiskinan di Perdesaan Lereng Merapi Selatan. Journal Humaniora Vol 14, Nomor 1, April 2009, ISSN 1412 - 4009.

Nasruddin Anshoriy dan Sudarsono. 2008. Kearifan Lingkungan: dalam Perspektif Budaya Jawa. Jakarta: Yayasan Obor Indonesia.

Suparmoko. 1994. Ekonomi Sumberdaya Alam dan Lingkungan. Yogyakarta: BPFE UGM. UNDP. 2006. Era Baru Dalam Pengentasan Kemiskinan. Jakarta: The World Bank Office.

Vidhyandika Moeljarto. 1996. Pemberdayaan Kelompok Miskin Melalui IDT dalam Onny S Priyono dan AMW Pranarka, Pemberdayaan Konsep, Kebijakan dan Implementasi, Jakarta: CSIS.

Depdikbud, 1988. Kamus Besar Bahasa Indonesia. Balai Pustaka. Jakarta.

Fandeli, Chafid, 1997. Dasar-dasar Manajemen Kepariwisataan Alam. Liberty. Yogyakarta. Kodhyat H, 1996. Sejarah Pariwisata dan Perkembangannya di Indonesia. Grasindo. Jakarta.

Lubis, Hari dan Husaini, Martani, Teori-Teori Organisasi. Grasindo. Jakarta.

Miles, Matthew B dan Huberman, A. Michael, 1992. Analisis Data Kualitatif. UI Press. Jakarta.

Moleong, Lexy J, 2002. Metode Penelitian Kualitatif. PT. Remaja Rosdakarya. Bandung. Pendit,

Nyoman S, 1999. Ilmu Pariwisata Sebuah Pengantar Perdana. PT. Pradnya Paramita. Jakarta.

Radiawan, Hari, Hartati, dan Soepomo, Sri Sadah, 1997/1998. Pengembangan Jaringan Ekonomi di Kawasan Pariwisata. CV : Bupara Nugraha. Jakarta.

Soekadijo, R. G, 1997. Anatomi Pariwisata : Memahami Pariwisata Sebagai Sistem Linkage. Gramedia Pustaka Utama. Jakarta.

Spillane, James, J, 1994. Pariwisata Indonesia : Siasat Ekonomi dan Rekayasa Kebudayaan. Kanisius. Yogyakarta.

Sutopo, HB, 2002. Metode Penelitian Kualitatif : Dasar Teori dan Penerapannya dalam Penelitian. UNS Press. Surakarta.

Suwantoro, Gamal, 1997. Dasar-dasar Pariwisata. ANDY. Yogyakarta.

Wahab, Salah dkk, 1997. Pemasaran Pariwisata. PT. Pradnya Paramita. Jakarta. Yoeti, Oka A, 1997. Pengantar Ilmu Pariwisata. Angkasa. Bandung. 